\title{
Improving the Quality of Higher Education Based on the Positive Image of HEE in the Social and Information Space: Legal and Management Aspects
}

\author{
VIKTOR HORODOVENKO ${ }^{1}$, OLENA BILOVODSKA ${ }^{2}$, VOLODYMYR VATRAS ${ }^{3}$, \\ ILONA KANZAFAROVA ${ }^{4}$, ROMAN MELNYK ${ }^{5}$ \\ ${ }^{1}$ CONSTITUTIONAL COURT OF UKRAINE, UKRAINE, E-mail: horodovenko@ccu.gov.ua \\ ${ }^{2}$ Department of Marketing and Communication Design, KYIV NATIONAL UNIVERSITY OF TECHNOLOGIES AND \\ DESIGN, UKRAINE, E-mail: alenabel79@gmail.com \\ ${ }^{3}$ Department of Civil Law and Procedure, KHMELNYTSKY UNIVERSITY OF MANAGEMENT AND LAW, UKRAINE, \\ E-mail: vatrasv@gmail.com \\ ${ }^{4}$ Department of Civil Law Disciplines, ODESA I.I. MECHNIKOV NATIONAL UNIVERSITY, UKRAINE, \\ E-mail: ilona-stanislav@ukr.net \\ ${ }^{5}$ Administrative Law Department, TARAS SHEVCHENKO NATIONAL UNIVERSITY OF KYIV, UKRAINE, \\ E-mail: applaw@uni.kiev.ua
}

\begin{abstract}
In the paper the authors improved the methodological approach to quantitative assessment of the image of a higher education establishment (HEE). This approach is based on the structure of the image of higher education establishment (educational process quality, training costs, visual characteristics of higher education establishments, stability of student intake and employment graduates, educational and extracurricular work as for applicants, corporate culture and traditions) for selected target audiences, provides comprehensive assessment and takes into account the significance (weight) of selected parameters evaluation. The image of higher education establishments was evaluated for three groups of the target audience: applicants, their parents and first-year students of higher education establishments of Ukraine. It was based on the real data of existing higher education establishments of Ukraine and EU, and online survey of 756 people. The author's approach is important for the general approach to the management of the HEE image, analysis and selection of forms, methods, mechanisms and tools of such management, search and justification of the place and role of image management in the management of the entire higher education establishment.
\end{abstract}

Keywords: Image assessment; Higher education establishment; Educational process; Information; Online survey; Target audience; Legal aspects of higher education establishments' activity.

JEL classification: I 23, M 31, K 29 


\title{
La Mejora de la Calidad de la Educación Superior Basada en la Imagen Positiva de la EES en el Espacio Social y de la Información: Aspectos Jurídicos y de Gestion
}

\author{
VIKTOR HORODOVENKO ${ }^{1}$, OLENA BILOVODSKA ${ }^{2}$, VOLODYMYR VATRAS ${ }^{3}$, \\ ILONA KANZAFAROVA ${ }^{4}$, ROMAN MELNYK ${ }^{5}$ \\ ${ }^{1}$ CONSTITUTIONAL COURT OF UKRAINE, UKRAINE, E-mail: horodovenko@ccu.gov.ua \\ ${ }^{2}$ Department of Marketing and Communication Design, KYIV NATIONAL UNIVERSITY OF TECHNOLOGIES AND \\ DESIGN, UKRAINE, E-mail: alenabel79@gmail.com \\ ${ }^{3}$ Department of Civil Law and Procedure, KHMELNYTSKY UNIVERSITY OF MANAGEMENT AND LAW, UKRAINE, \\ E-mail: vatrasv@gmail.com \\ ${ }^{4}$ Department of Civil Law Disciplines, ODESA I.I. MECHNIKOV NATIONAL UNIVERSITY, UKRAINE, \\ E-mail: ilona-stanislav@ukr.net
} ${ }^{5}$ Administrative Law Department, TARAS SHEVCHENKO NATIONAL UNIVERSITY OF KYIV, UKRAINE, E-mail: applaw@uni.kiev.ua

\begin{abstract}
RESUMEN
En el artículo los autores mejoraron el enfoque metodológico para la evaluación cuantitativa de la imagen de un establecimiento de educación superior (HEE). Este enfoque se basa en la estructura de la imagen de los centros de enseñanza superior (calidad del proceso educativo, costes de formación, características visuales de los centros de enseñanza superior, estabilidad de la admisión de estudiantes y de los graduados en el empleo, trabajo educativo y extracurricular en cuanto a los solicitantes, cultura corporativa y tradiciones) para los públicos objetivo seleccionados, proporciona una evaluación exhaustiva y tiene en cuenta la importancia (peso) de la evaluación de los parámetros seleccionados. La imagen de los centros de enseñanza superior se evaluó para tres grupos del público objetivo: los solicitantes, sus padres y los estudiantes de primer año de los centros de enseñanza superior de Ucrania. Se basó en los datos reales de los centros de enseñanza superior existentes en Ucrania y en la UE, y en una encuesta en línea realizada a 756 personas. El planteamiento del autor es importante para el enfoque general de la gestión de la imagen de los centros de enseñanza superior, el análisis y la selección de las formas, los métodos, los mecanismos y las herramientas de dicha gestión, la búsqueda y la justificación del lugar y el papel de la gestión de la imagen en la gestión de todo el centro de enseñanza superior.
\end{abstract}

Palabras claves: Evaluación de la imagen; Centro de enseñanza superior; Proceso educativo; Información; Encuesta en línea; Público objetivo; Aspectos jurídicos de la actividad de los centros de enseñanza superior

Clasificacion JEL: I 23, M 31, K 29

Received: 08 de abril de 2021

Aceptado: 12 de junio de 2021 


\section{Introduction}

The situation in the Ukrainian market of educational services is becoming more tense every year. The main reasons for this are, firstly, the strict selection of educational establishments that seek to work in the market. It should be noted that the market has a significant number of commercial establishments, which due to mobility, developed material and technical base and flexible pricing policy, provide a gradual increase in market share of educational services. Second, the reduction of budget funding for higher education requires establishments to constantly seek other sources of financial resources for their sustainable development. In addition, in market conditions, not only applicants compete with each other to enter the chosen establishment of higher education, educational establishments are also forced to compete in the struggle for applicants. Under such conditions, more and more attention is paid to the problem of ensuring the competitiveness of higher education establishments (Babenko et al., 2020; Bila et al., 2019; Bilovodska et al., 2017; Kholiavko et al., 2020; Olshanska et al, 2020; Perevozova et al., 2020). One of the most effective means of competition is purposeful work on managing the image of a higher education establishment. Image management contains a significant number of functions, a special place among which is the evaluation of the image in the information space.

The process of evaluating and improving the image of higher education establishments is becoming especially relevant today due to the projected demographic decline, outflow of applicants to foreign establishments, reduced motivation of students, etc., which will reduce demand for educational services and hence increased competition. That is why higher education establishments should pay considerable attention to the process of comprehensive assessment and image improvement.

Economic literature provides a variety of indicators for measuring corporate image. I. Aloshyna and B. Dzhi. write that assessment of the image of the enterprise should be made by experts on the basis of the analysis of the corresponding system of indicators existing under informal circumstances, own experience, intuition (Aloshina, 1997; Dzhi, 2000).

K. Babych, and I. Lakhno offer to limit the number of studied factors of the company's image and on this basis to build a comprehensive indicator of its evaluation (Babych et al., 1997).

For the purpose of assessing an image, R. Akoff offers to use interview methods - both direct and project-based, which based on associations (Akoff, 2000).

Yevtushenko G., Pilipchuk V. and Smirnova N. reveal the essence of the concept of image of higher education establishment, study and analyze its main components, determine their features, consider in detail the impact of image of higher education on consumers of educational services and its rating among other higher education establishments, develop basic stages of image formation and offer recommendations (Yevtushenko et al., 2016).

Kouda V. O., Pasko M. I. examine the approaches to the creation of a positive image of an higher educational establishment (HEE) on the Ukrainian market for educational services in a competitive environment, which significantly affects the growth in the number of potential consumers and solvent applicants. The main elements of the image of HEE as a means and a tool, object of control, which is focused on target groups and, above all, applicants, are identified (Kouda et al., 2018).

Miroshnichenko D.A., Zlenko A.M., Isaykina O.D. define the essence of the meaning, examine the structure, research main stages of forming and systematization of theoretical positions about forming of corporative culture and image of HEE in the educational services market (Miroshnichenko et al., 2017).

Kostynets V., Kostynets Y. develop the model of brand assets management and substantiate the key elements of the brand which are to be assessed (Kostynets et al., 2013).

Azoury N., Daou L., Khoury C. investigate the relationships between the different components of the university image and to what extent they may affect the students' satisfaction (Azoury et al., 2014). 
Del-Castillo-Feito C., Blanco-González A., González-Vázquez E. measure the relationship between image and reputation in the context of Spanish Public Universities considering different university's stakeholder perceptions (Del-Castillo-Feito et al., 2019).

Patlán Pérez J., Martínez Torres E. evaluate the organizational image of an establishment of higher education. The stages of their research were: translation-retranslation of the original scale of organizational image; integration of scale items using a semantic differential response scale type; piloting of the scale with a sample of Autonomous University of Hidalgo State; determination of the psychometric properties of the scale, descriptive statistics of the scale and comparative analysis (Patlán Pérez et al., 2017).

Despite the considerable interest in the study of image by both domestic and foreign experts, most researchers ignore the issue of comprehensive assessment of the image of higher education establishments, which provides an effective choice of forms, methods, mechanisms and tools for its management (Alghamdi.A, 2020).

Therefore, the purpose of this study is to assess the image of higher education establishments based on the improvement of the methodological approach, which significantly increases the objectivity and accuracy of assessment.

\section{Materials and methods}

One of the important components of the Ukraine's integration process into the European Union is the deepening of cooperation in the field of higher education, which takes place within the framework of the Bologna Process. The implementation of Erasmus+ international academic mobility projects, made possible by Ukraine's accession to the Bologna Process, allows students to take advantage of study, internship and employment opportunities abroad. Similarly, foreign students received additional opportunities to come and study in Ukraine. In these circumstances, the "image" concept of the higher education establishment is paramount important and it's the main criterion for choosing an institution for education. Also the image of a higher education establishment plays a crucial role in the choice of a university for higher education by Ukrainian students. However, there is currently a gap in the implementation of a single state coordination of the procedure for forming and evaluating the image of a higher education establishment. The provisions and recommendations of the National Agency for Quality Assurance in Higher Education define the need to improve the quality of higher education and its individual components, which in general form the image of a higher education establishment. In particular, for example, it applies to finances, material and technical resources that ensure the educational process, transparency and publicity of HEE activities (Recommendations, 2020).

The activity of higher education establishments is regulated by a number of normative legal acts, the main ones being the Constitution of Ukraine (The Constitution, 1996), the State National Program "Education" ("Ukraine of the XXI Century") (THE State, 1993), the National Doctrine of Education Development (The National, 2002), the Law of Ukraine "On Higher Education" (The Law, 2014), Government of Ukraine resolution "On approval of licensing conditions for educational activities" (The Resolution, 2015), etc. The main functions are as follows: promoting the sustainable development of society by training competitive human capital and creating conditions for lifelong learning; promoting the availability of higher education; independence of higher education from political parties, public and religious organizations (except for establishments of higher spiritual education); promoting international integration and integration of the higher education system of Ukraine into the European Higher Education Area, provided that the achievements and progressive traditions of the national higher education are preserved and developed; promotion of state support for the training of specialists with higher education for priority areas of economic activity, areas of basic and applied research, scientific and pedagogical, artistic and pedagogical activities; state support of educational, scientific, technical, artistic and innovative activities of universities, academies, institutes, colleges, in particular by providing benefits for taxes, fees and other 
mandatory payments to higher education establishments engaged in such activities; implementation of public-private partnership in the field of higher education; promoting openness in the formation of the structure and scope of educational and professional training of specialists with higher education.

The methodological basis of the study is a set of scientific techniques and methods of scientific knowledge, including formal-logical method and comparative analysis, decomposition, structurallogical approach (in the study of image's structure of the of higher education establishments), criterion analysis, method of statistical series, method of expert assessments taking into account the coefficients of concordance and weight, ranking point evaluation, semantic differential (in the quantitative assessment of the higher education establishments' image).

\section{Results and discussion}

\subsection{Image structure of a higher education institute}

Carrying out the process of image assessment, it is necessary to have a clear idea of the very structure of the image of the higher education establishment (HEE). There are various elements of the image structure that determine the perception of HEE by real or potential consumers.

The choice of a modern applicant of a higher education establishment, on the one hand, is influenced by his awareness of the results of activities (quality of training, their demand in the labor market), and on the other - the information of the higher education establishment, reviews of its graduates and more. The idea of a higher education establishment is formed in the course of a person's personal contacts with him, on the basis of rumors circulating in society, as well as from media reports.

The main factors influencing the process of forming the image of a higher education establishment are: quality of educational services, prestige of specialties, level of foreign relations, speed of response to changes in consumer demands (applicants and employers), demand for graduates in the labor market, employment, corporate culture and traditions of the HEE, sociopsychological climate of the team, visual characteristics of the establishment of higher education (location and architecture of buildings), general popularity, reviews of the establishment of higher education of its graduates. Thus, on the basis of these factors, the structure of the image of higher education establishments is built (Fig. 1).

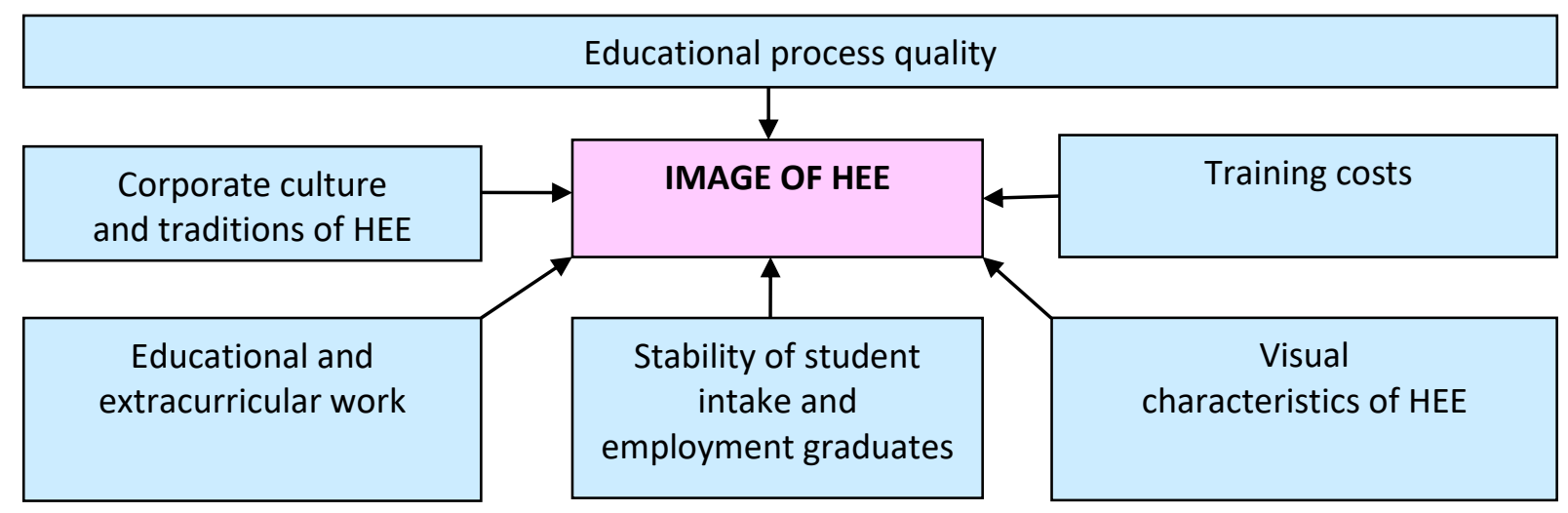

Figure 1. Author's approach to the formation of the image structure of the HEE

\section{Educational process quality.}

One of the main elements of the structure of the image of the HEE is the quality of the educational process, which contributes to the use of personal quality of educational services, the level of methodological and technical support.

Depending on their capabilities and consumer demands, higher education establishments in the market of educational services offer a wide range of educational programs.

The image of educational services is made up of people's ideas about the unique characteristics of 
these services of a higher education establishment. As unique characteristics are considered:

- availability of a wide range of licensed specialties and accredited educational programs;

- quality of teaching disciplines;

- quality of knowledge and ability to use it in practice and professional activity;

- teaching methods (availability of case technologies, trainings, presentations, business games, discussions, excursions to the enterprises of the city);

- the information content of distance learning;

- diverse educational environment that provides consumers of educational services with opportunities for self-realization;

- availability of additional services: the possibility of retraining and advanced training after graduation;

- the presence of international relations in the higher education establishment (the possibility of obtaining international recognition of diplomas, training in student exchange programs, international relations and partnership of the educational establishment, etc.);

- foreign teachers' presence (involvement of well-known teachers from foreign universities).

The introduction of the so-called "virtual learning environment" through an extensive information and communication system (number of computers, multimedia projectors, network classes, etc.) also has a great impact on improving the quality of student training.

\section{Training costs.}

When choosing a higher education establishment, most applicants (especially their parents) pay special attention to the level of training costs for educational services. For many applicants and students this factor is the most important, because there is a wish to get a good education at an affordable price. Therefore, a detailed analysis of the pricing policy of all HEE is made and the most attractive option is chosen.

For many higher education establishments, the issue of pricing is the most relevant. For example, private higher education establishments seek to ensure a certain level of profitability of their own educational activities and therefore pursue a very prudent pricing policy. But on the other hand, the low price of educational services can form in the minds of consumers the idea of low quality of the educational program.

Basically, when choosing a HEE and educational program, today the consumer pays attention to two main indicators: the quality of the educational program and the costs associated with the acquisition and operation of educational services.

In general, educational services are a very specific product. It have a high consumer value because it increases the intellectual potential of the individual, future workers or professionals. In developed markets, this is reflected in the high cost of skilled labor, the legitimacy of high prices for educational services. Educational services are characterized by the length of the period of their provision, delayed identification of the effectiveness of educational services and the dependence of the effectiveness of graduates of higher education establishments on their working and living conditions.

\section{Visual characteristics of higher education establishments.}

The visual image of HEE is a view of an establishment formed on the basis of visual sensations. This view is recorded on the basis of information about the infrastructure of HEE (the design of buildings, the convenience of classrooms and ancillary facilities), design and content of the site.

For students and their parents, an important image point is the infrastructure of the higher education establishment: a quality student canteen, gym, libraries, the level of improvement of dormitories.The visual characteristics also include the location of the HEE, architectural image of buildings (buildings), design of premises, spaciousness of auditoriums.

The structure of HEE image includes elements like the image symbols: name, coat of arms, 
anthem, flag, uniform, logo, slogan, motto and overall corporate identity. It all adds additional (desirable) elements to the image of a higher education establishment.

Each higher education establishment has its own corporate design, which includes the presence of logo, anthem and flag of the higher education establishment. For example, the logo is used in the design of business documents, in advertising, in the design of premises. A successful logo is well remembered, evokes associations, emphasizes originality. It should reflect the characteristics of a HEE and its traditions.

\section{Stability of student intake and employment graduates.}

Each higher education establishment tries to maintain its share in the market of educational services by maintaining the stability of student enrollment. After all, significant fluctuations in the number of applicants indicate a certain instability of the educational establishment, reducing its popularity and prestige.

The annual increase in the competitive passing score and the number of people per place indicates to the applicant the demand for educational services of a higher education establishment.

In addition, a HEE presents the results of its activities (specialists) in the labor market, whose consumers are enterprises and organizations in various industries. In fact, a HEE presents the results of its own activities in the form of the competencies of its graduates.

Every higher education establishment tries to provide employment for its graduates. Higher education establishments organize career days, job fairs, and recommend talented students to leading companies and organizations. In any case, the high level of employment is of interest to the applicant, because it gives some confidence in the possibility of getting a decent job after graduation. In addition, it is important to cooperate with foreign countries, the availability of academic mobility.

\section{Educational and extracurricular work.}

The development of the extracurricular sphere of student life plays not the least role in the formation of the overall image of the establishment of higher education. Thus, the active work of student government and student unions indicates a high level of student participation in the life of higher education.

An important role here is also played by the level of amateur performances (quality of concert programs and the number of students involved), the presence of sports sections and clubs.

\section{Corporate culture and traditions of HEE.}

Corporate culture is a distinctive feature of higher education. It consists of explicit and implicit repetitive behaviors. The corporate culture of a HEE contains the following important elements:

a) a HEE mission (strategic goal that reflects the meaning of existence, the role that the HEE wants to play in society);

b) corporate philosophy (core values, priorities, guidelines of the HEE).

Thus, the organizational (corporate) culture of a HEE is:

- supported by all or almost all members of the HEE: from management (rector) to student;

- passing from members of the HEE;

- forming the behavior of students (morals, laws, customs, traditions) and the structure of their perception and vision of the world;

- poorly susceptible to change;

- forming a system of connections after graduation.

If for the analysis of organizational culture of HEE to use methodology of level interpretation of E. Schein (Schein et al., 2016), then according to this concept, the corporate culture of HEE can look like this (Fig. 2).

The upper level of the cultural system of a higher education establishment is a set of directly 
visible events and phenomena. These are the formal role structure of a HEE, leadership style, communication systems, organizational procedures, social technologies, traditions, rituals, customs, language, etc. It is with their help that the establishment of higher education fulfills its tasks and mission. Potential consumers of educational services pay attention to them in the first place.

The middle level of the cultural system of a HEE is represented by its norms, values, beliefs, which are not subject to direct observation, but are reflected in the behavior of staff (administration, faculty, etc.).

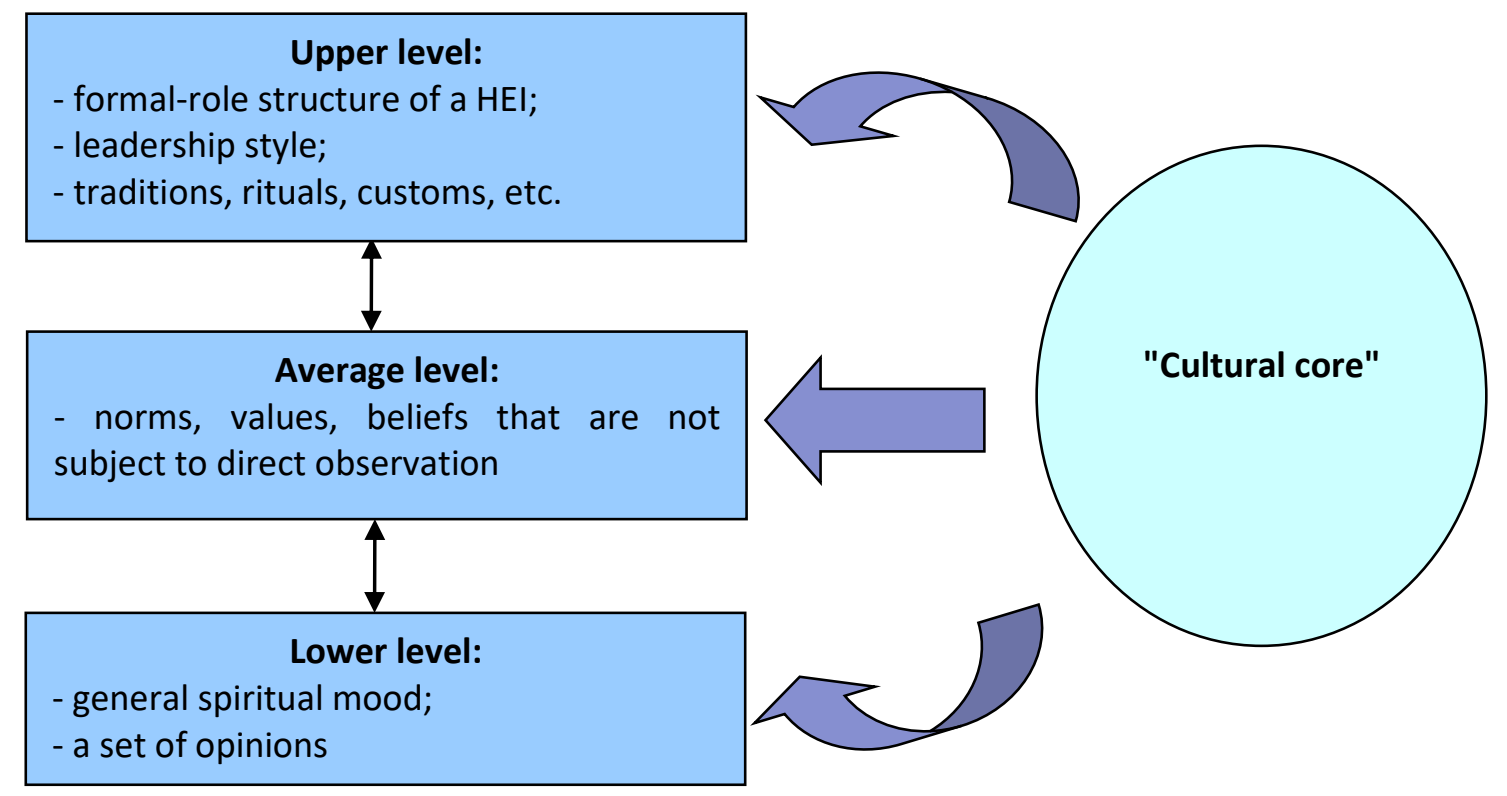

Figure 2. Corporate culture of HEE (by level interpretation) (Schein et al., 2016)

The lower level of the cultural system consists of the "basic ideas" of the workers, which means the general spiritual mood, the set of opinions that make up the overall picture of a HEE.

Schein E. and Schein P. introduce the concept of "cultural core", which means the collective consciousness of higher education. It is the primary one that defines the whole cultural system. These include examples of behavior of leaders of student movements, as well as the team of the rector and vice-rectors (Schein et al., 2016).

Thus, the structure of the image contains a certain list of elements that affect the perception of the HEE applicants and students, society in general. The division of the concept of "image" into constituent components shows that each component is important for the overall image of the establishment of higher education. In order to properly manage the image of a higher education establishment, it is necessary to monitor which elements and to what extent contribute to the strengthening of the image, which of them should be given special attention.

\subsection{Author's approach to quantitative assessment of the image of a higher education establishment}

Scientists claim that almost the entire range of methods for studying consumer attitudes can be used to assess an image, including the semantic differential, consumer prototypes, building various scales, psycholinguistics, and more (Muhammad et al 2020).

The study improved the quantitative method of image evaluation, which includes elements of the semantic differential (improved, using weights). The essence of this approach is to derive a weighted average assessment of the image of a higher education establishment. Fig. 3 presents the stages of quantitative assessment of the image.

A score of image elements is taking as initial information. The set of elements (parameters) for assessing the image of higher education establishments is not universal, but is determined by their 
specificity (see the previous paragraph of this study) and is represented by a semantic differential (Mykytiuk, 2001). The selected elements (parameters) are evaluated on a 5-point scale, within which are bipolar statements, where the score of " 5 points" corresponds to the best value of the parameter, "1 point" - the worst value. Next, statistical series are constructed in the form of Table 1.

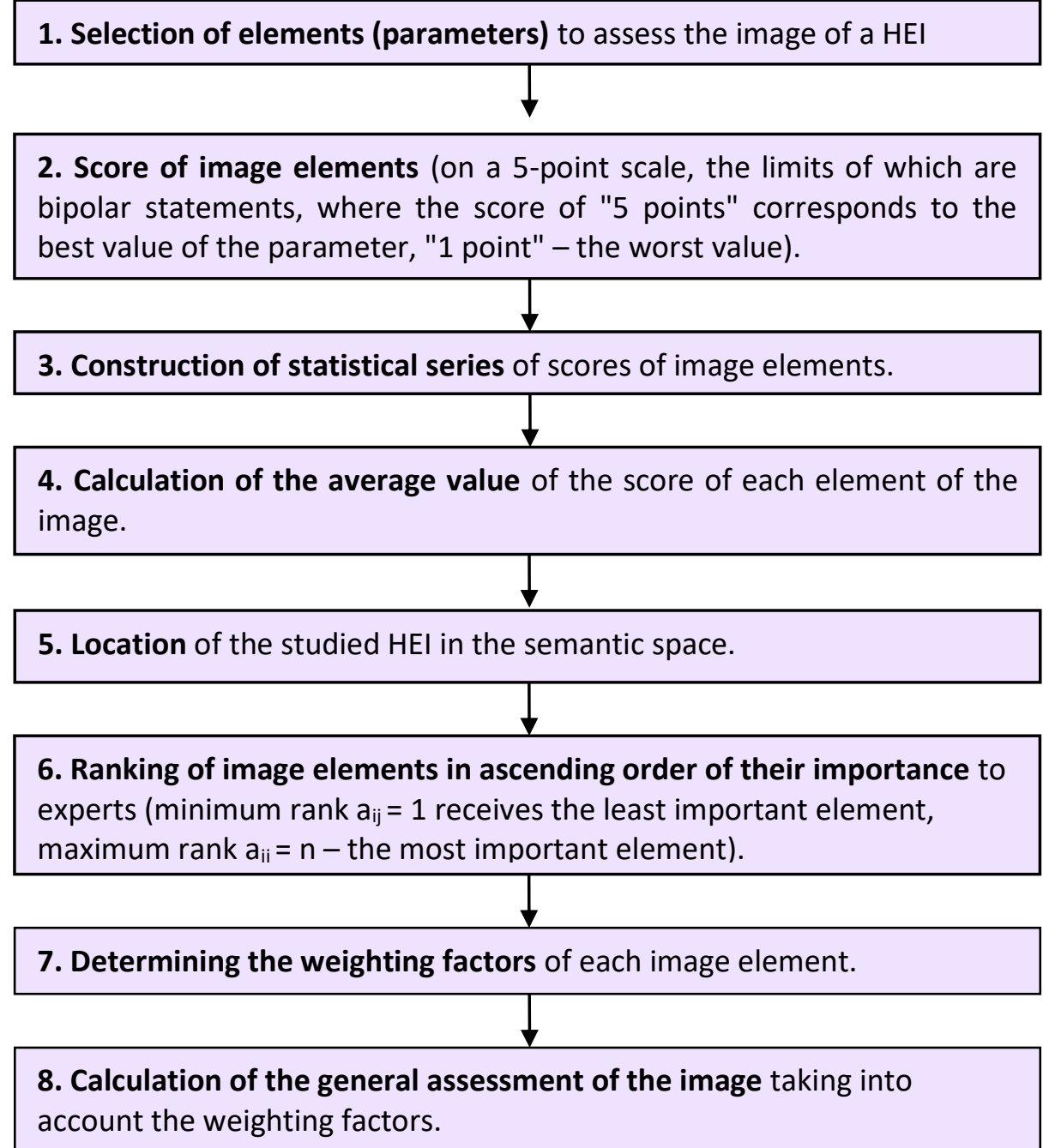

Figure 3. Stages of quantitative assessment of the image

Table 1. Statistical series

\begin{tabular}{|c|c|c|c|c|c|}
\hline Indicator & \multicolumn{5}{|c|}{ Value } \\
\hline $\mathbf{x}_{\mathbf{i}}$ & 1 & 2 & 3 & 4 & 5 \\
\hline $\mathrm{n}_{\mathbf{i}}$ & $\mathrm{n}_{1}$ & $\mathrm{n}_{2}$ & $\mathrm{n}_{3}$ & $\mathrm{n}_{4}$ & $\mathrm{n}_{5}$ \\
\hline
\end{tabular}

$x_{i}$ - assessment of a certain parameter (image element) on a 5-point scale;

$n_{i}-$ frequency value $x_{i}$, means how many times the score was set $x_{i}$ when assessing the image of a certain element of the image by all respondents in the aggregate.

The average value of the score of each investigated element is calculated by the formula:

$$
X_{i}=\frac{1}{K} \sum_{i=1}^{5} x_{i} n_{i},
$$

where $K$ is the number of respondents.

The average value of $X_{i}$ is an indicator of the total assessment of this image element by all respondents. In this case, the average value is a fairly objective characteristic, as it allows to 
neutralize the influence of subjective factors (for example, the bias of individual respondents in relation to this HEE at the time of the survey).

Next, it is necessary to place the studied HEE in the semantic space. The results are quite obvious and quite easy to interpret and it becomes clear on what elements of the image of a particular HEE is better or worse in comparison with the main competitors. The semantic space also makes it possible to determine which establishment of higher education is closest to the ideal.

To increase the accuracy of the assessment, this approach has been improved and it is proposed to take into account the importance of each parameter (image element). Therefore, after determining the score of each of the studied parameters, it is necessary to apply the ranking method. Ranking involves the arrangement of parameters (elements) in the order of their preference or importance. To do this, experts (respondents) are asked to rank (arrange) the elements in ascending order of importance, so the least important element receives the minimum rank $a_{i j}=1$. The next, least important of the remaining parameters receives the rank $a_{i j}=2$ and so on.

Next, the weights $\left(q_{i}\right)$ determine by the formula:

$$
\mathrm{q}_{i}=\frac{\mathrm{a}_{\mathrm{i}}}{\mathrm{Sa}_{\mathrm{i}}},
$$

where $a_{i}$ is the sum of points assigned by all respondents (experts) to indicator i (image element);

$\mathrm{Sa}_{i}$ - the sum of points assigned by all respondents for all indicators.

The overall assessment of the image, taking into account the weight of its elements is calculated by the formula:

$$
I_{3}=\sum_{i=1}^{n} x_{i} \times q_{i}
$$

$\mathrm{n}$ - the number of image elements.

Therefore, on the basis of this approach, the overall assessment of the image is calculated not only in accordance with the assessments of the components of the HEE image, but also taking into account their importance for respondents (experts).

The overall level of assessment largely depends on the "segment gaps" (different target groups), which is due to the different priorities of different segments and the degree of importance of the parameters for them. In this regard, the importance of image elements for the target groups is assessed by determining the weighted average score.

Once the image evaluation has been performed and the integrated summary evaluations of competing objects have been obtained and finally their comparative profile has been constructed, then we have to check image variations. The obtained results will not indicate a clearly positive or negative image; it will be somewhat vague. There is an opinion that it is better to develop a vague image so that different target audiences can form an idea of the HEE from different points of view.

According to the authors, the proposed approach to quantifying the image is quite effective, because it has such advantages:

a) the image assessment is comprehensive;

b) assessment of the HEE image is carried out according to the criteria that are specific to this industry (educational services);

c) image assessment is carried out by taking into account the elements that are ranked by their importance (weight), which significantly increases the objectivity and accuracy of the assessment;

d) The data obtained as a result of the application of this approach allow us to conclude which specific areas of HEE activity need to be improved. 


\subsection{Practical principles of assessing the image of higher education establishments}

Our main task here is to correctly identify the target audience. Identifying the target audience means clearly imagining who will be potential consumers of educational services, which categories of clients are already such, which individuals influence the decision-making process.

It should be borne in mind that the role of the audience are not only applicants but also other members of the public, as they have their own idea of the image of a particular establishment of higher education. Fig. 4 lists the main representatives of the target audience, which must be taken into account when assessing the image of higher education establishments.

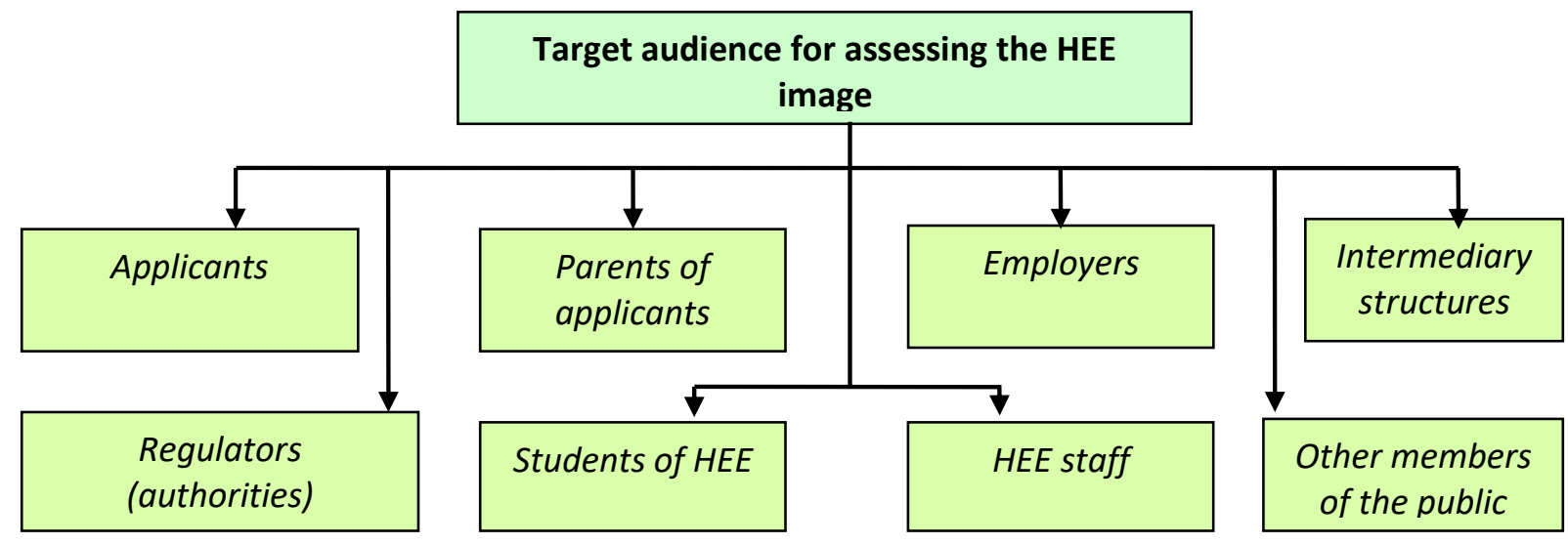

Figure 4. Representatives of the target audience to assess the image of HEE

1. Applicants. The greatest attention in assessing the image should be paid to potential consumers of educational services (applicants). In most cases, they make the final choice of a higher education establishment;

2. Parents of applicants are generally interested in the choice of their children (applicants). In some ways, they also influence the decision to choose a HEE, especially when future education will be at their own expense. Therefore, care should be taken to create a positive image of a HEE for parents of applicants;

3. Employers. Enterprises and organizations of various industries are interested in attracting good professionals - graduates of prestigious higher education establishments. Therefore, in the eyes of the main employers, schools should look like promising establishments of higher education, have a positive image;

4. Intermediary structures in the market of educational products and services. Such structures include employment services, labor exchanges, associations of educational establishments, and so on. The data of the representatives of the target audience also have their own idea about a particular HEE; alumni association;

5. Regulators (authorities) (Ministry of Education and Science of Ukraine, National Agency for Quality Assurance in Higher Education, etc.). Based on the results of higher education establishments, representatives of regulatory bodies have their own opinions about HEEs;

6. Students of HEE. When assessing the image of a HEE should pay attention to such a target audience as students. They in a way play the role of carriers of the image of the HEE;

7. HEE staff: HEE administration, professors, etc. The opinion of these representatives about a HEE is formed on the basis of their own experience. They have personal beliefs about the image of the HEE, its prestige in the market of educational services;

8. Other members of the public. Rumors circulating in society also affect the perception of a particular HEE. Thus, applicants discuss with acquaintances and friends the advantages and disadvantages of admission to a particular HEE. On the basis of such oral discussions, the applicants 
form a certain image of the establishment of higher education.

Due to the heterogeneity of the audience that evaluates an object (higher education establishment), the heterogeneity of the image is formed. The evaluation of a HEE can cover its various aspects, due to a number of factors, among which the priority is given to the relationship that the audience has with the HEE. Namely: what level of awareness about the HEE, what experience has already developed and based on what information, etc.

The authors assessed the image of higher education establishments on the basis of an improved approach containing elements of semantic differential (semantic differential using weighting factors) and a survey of three groups of target audience: applicants, their parents and first-year students of three higher education establishments (the names are not given for reasons of non-admission of the text of an advertising nature or discriminatory features). The research is based on real data of existing higher education establishments of Ukraine and EU, and online survey of 756 people (based on the materials and methods in (Bilovodska et al., 2020; Chmutova et al., 2017; Bilovodska et al., 2021).

To quantify the image in the questionnaire for interviewing respondents, the authors used a series of bipolar statements in the form of a 5-point scale. Next, statistical score series were constructed (Tables 2-4).

The table 2 presents the score of the image of the HEE applicants.

Table 2. Score of the image parameters of higher education establishments by applicants (number of answers, pcs.)

\begin{tabular}{|c|c|c|c|c|c|c|c|c|c|c|c|c|c|c|c|c|}
\hline \multirow{3}{*}{ № } & \multirow{3}{*}{ Image parameter } & \multicolumn{15}{|c|}{ Score (in points) } \\
\hline & & \multicolumn{5}{|c|}{ HEE 1} & \multicolumn{5}{|c|}{ HEE 2} & \multicolumn{5}{|c|}{ HEE 3} \\
\hline & & 1 & 2 & 3 & 4 & 5 & 1 & 2 & 3 & 4 & 5 & 1 & 2 & 3 & 4 & 5 \\
\hline 1. & $\begin{array}{l}\text { The quality of } \\
\text { educational process } \\
\left(X_{1}\right)\end{array}$ & 3 & 12 & 21 & 34 & 25 & 3 & 12 & 21 & 36 & 23 & 1 & 10 & 24 & 28 & 32 \\
\hline 2. & Training costs $\left(X_{2}\right)$ & 25 & 26 & 14 & 19 & 11 & 12 & 24 & 21 & 21 & 17 & 14 & 16 & 24 & 30 & 11 \\
\hline 3. & $\begin{array}{l}\text { Visual characteristics } \\
\text { of a HEE }\left(X_{3}\right)\end{array}$ & 2 & 4 & 23 & 25 & 41 & 5 & 17 & 26 & 19 & 28 & 8 & 13 & 21 & 11 & 42 \\
\hline 4. & $\begin{array}{l}\text { Stability of student } \\
\text { enrollment and } \\
\text { employment } \\
\text { opportunities after } \\
\text { graduation }\left(\mathrm{X}_{4}\right)\end{array}$ & 4 & 12 & 24 & 31 & 24 & 11 & 17 & 19 & 30 & 18 & 1 & 3 & 14 & 29 & 48 \\
\hline 5. & $\begin{array}{l}\text { Educational and } \\
\text { extracurricular work } \\
\left(X_{5}\right)\end{array}$ & 0 & 3 & 21 & 28 & 43 & 1 & 11 & 15 & 26 & 42 & 2 & 5 & 19 & 31 & 38 \\
\hline 6. & $\begin{array}{l}\text { Corporate culture and } \\
\text { traditions of HEE }\left(X_{6}\right)\end{array}$ & 2 & 9 & 27 & 31 & 26 & 2 & 17 & 21 & 33 & 22 & 3 & 4 & 23 & 38 & 27 \\
\hline
\end{tabular}

The calculated average value of the score of applicants for each studied element of the HEE 1 image, using the formula:
a) $X_{1}=\frac{1 \times 3+2 \times 12+3 \times 21+4 \times 34+5 \times 25}{95}=3,69$;
b) $x_{2}=\frac{1 \times 25+2 \times 26+3 \times 14+4 \times 19+5 \times 11}{95}=2,63$;
c) $X_{3}=\frac{1 \times 2+2 \times 4+3 \times 23+4 \times 25+5 \times 41}{95}=4,04$;
d) $X_{4}=\frac{1 \times 4+2 \times 12+3 \times 24+4 \times 31+5 \times 24}{95}=3,62$; 
e) $X_{5}=\frac{1 \times 0+2 \times 3+3 \times 21+4 \times 28+5 \times 43}{95}=4,17 ; \quad$ f) $X_{6}=\frac{1 \times 2+2 \times 9+3 \times 27+4 \times 31+5 \times 26}{95}=3,74$

Similarly, the average values of the score of the applicants of each studied element of the image of the HEE 2 and the HEE 3 were calculated. As a result of calculations, the following values were obtained for the HEE $2: X_{1}=3,67 ; X_{2}=3,07 ; X_{3}=3,51 ; X_{4}=3,28 ; X_{5}=4,02 ; X_{6}=3,59 ; 3 B O 3: X_{1}=3,87$; $x_{2}=3,08 ; x_{3}=3,69 ; x_{4}=4,26 ; x_{5}=4,03 ; x_{6}=3,86$.

The total (average) assessment of the elements of the image of HEE 1, HEE 2 and HEE 3 by all respondents (applicants) is presented in Fig. 5.

\section{Score in points}

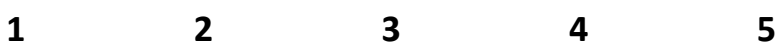

Low quality of the educational process

High tuition fees

Unattractive visual characteristics

Low enrollment of HEE applicants and low employment opportunities after graduation

Uninteresting educational and extracurricular work

Underdeveloped corporate culture and

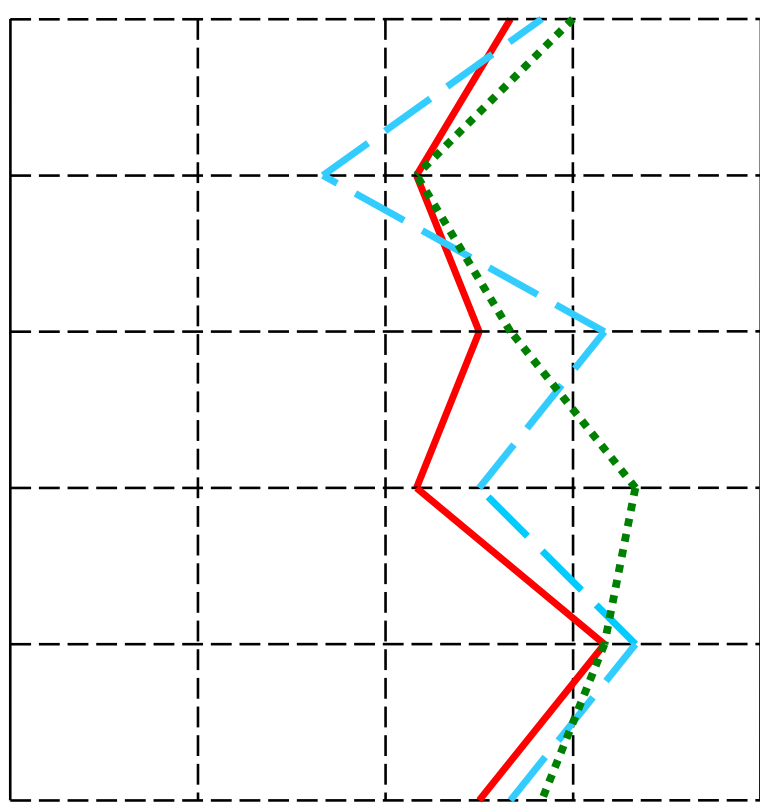
traditions of HEE
High quality of the educational process

Low tuition fees

Attractive visual characteristics

High enrollment of HEE applicants and high employment opportunities after graduation

Interesting educational and extracurricular work

Developed corporate culture and traditions of HEE

\section{- $=$ HEE 1 HEE 2 HEE 3}

Figure 5. Assessment of the image of higher education establishments by applicants

The results are quite clear and easy to interpret. From fig. 6 shows that the strongest positions in the eyes of applicants are HEE 3 and HEE 1. HEE 1 it is advisable to improve such an element of image as the training costs (because it is this parameter image HEE significantly loses to its competitors), as well as to improve the quality of the educational process and expanding employment opportunities for students and graduates. HEE 2 has a losing position in almost all elements (parameters), except for the pricing policy, in relation to HEE 1 and only in terms of educational, extracurricular activities and the training costs on an equal footing competes with HEE 3 . HEE 3 is significantly ahead of both comparable establishments. stability of enrollment of students and employment opportunities for graduates (Fig. 5).

The table 3 presents the score of the image of a HEE by parents of applicants. 
Improving the Quality of Higher Education Based on the Positive Image of HEE in the Social and Information Space: Legal and Management Aspects

Table 3. Score of the parameters of the image of HEE by the parents of applicants (number of answers, pcs.)

\begin{tabular}{|c|c|c|c|c|c|c|c|c|c|c|c|c|c|c|c|c|}
\hline \multirow{3}{*}{ № } & \multirow{3}{*}{ Image parameter } & \multicolumn{15}{|c|}{ Score (in points) } \\
\hline & & \multicolumn{5}{|c|}{ HEE 1} & \multicolumn{5}{|c|}{ HEE 2} & \multicolumn{5}{|c|}{ HEE 3} \\
\hline & & 1 & 2 & 3 & 4 & 5 & 1 & 2 & 3 & 4 & 5 & 1 & 2 & 3 & 4 & 5 \\
\hline 1. & $\begin{array}{l}\text { The quality of } \\
\text { educational process }\left(X_{1}\right)\end{array}$ & 4 & 6 & 21 & 24 & 40 & 12 & 13 & 21 & 31 & 18 & 2 & 11 & 24 & 27 & 31 \\
\hline 2. & Training costs $\left(\mathrm{X}_{2}\right)$ & 20 & 24 & 14 & 15 & 22 & 22 & 29 & 23 & 16 & 5 & 34 & 31 & 13 & 10 & 7 \\
\hline 3. & $\begin{array}{l}\text { Visual characteristics of } \\
\text { a } \operatorname{HEE}\left(\mathrm{X}_{3}\right)\end{array}$ & 0 & 10 & 17 & 35 & 33 & 1 & 6 & 25 & 31 & 32 & 6 & 17 & 20 & 31 & 21 \\
\hline 4. & $\begin{array}{l}\text { Stability of student } \\
\text { enrollment and } \\
\text { employment } \\
\text { opportunities after } \\
\text { graduation }\left(X_{4}\right)\end{array}$ & 4 & 16 & 28 & 31 & 16 & 1 & 13 & 21 & 25 & 35 & 10 & 13 & 24 & 28 & 20 \\
\hline 5. & $\begin{array}{l}\text { Educational and } \\
\text { extracurricular work }\left(X_{5}\right)\end{array}$ & 1 & 20 & 23 & 35 & 16 & 2 & 14 & 21 & 31 & 27 & 5 & 10 & 19 & 22 & 39 \\
\hline 6. & $\begin{array}{l}\text { Corporate culture and } \\
\text { traditions of HEE }\left(\mathrm{X}_{6}\right)\end{array}$ & 3 & 17 & 21 & 30 & 24 & 2 & 11 & 19 & 38 & 25 & 2 & 6 & 25 & 27 & 35 \\
\hline
\end{tabular}

The average value of the score of parents of applicants for each studied element of the HEE 1 image is:
a) $X_{1}=\frac{1 \times 4+2 \times 6+3 \times 21+4 \times 24+5 \times 40}{95}=3,95$;
b) $X_{2}=\frac{1 \times 20+2 \times 24+3 \times 14+4 \times 15+5 \times 22}{95}=2,95$;
c) $X_{3}=\frac{1 \times 0+2 \times 10+3 \times 17+4 \times 35+5 \times 33}{95}=3,96$;
d) $X_{4}=\frac{1 \times 4+2 \times 16+3 \times 28+4 \times 31+5 \times 16}{95}=3,41$;
e) $X_{5}=\frac{1 \times 1+2 \times 20+3 \times 23+4 \times 35+5 \times 16}{95}=3,47$;
f) $X_{6}=\frac{1 \times 3+2 \times 17+3 \times 21+4 \times 30+5 \times 24}{95}=3,58$.

Similarly, the average values of the score of parents of applicants for each studied element of the HEE 2 and HEE 3 image were calculated. As a result of calculations the following values for HEE 2 are received: $X_{1}=3,22 ; X_{2}=2,51 ; X_{3}=3,92 ; X_{4}=3,84 ; X_{5}=3,71 ; X_{6}=3,77 ; 3 B O 3: X_{1}=3,78 ; X_{2}=2,21 ; X_{3}=$ 3,$46 ; X_{4}=3,37 ; X_{5}=3,84 ; X_{6}=3,92$.

The total (average) assessment of the image elements of HEE 1, HEE 2, HEE 3 by all respondents (parents of applicants) is presented in Fig. 6.

Assessing the set of criteria, we can conclude that in the opinion of parents of applicants, closest to the ideal is the HEE 1 image. However, this higher education establishment should improve such image elements as the stability of recruitment and employment opportunities after graduation (as well as acquisition of employment skills while studying in HEE), as well as educational and extracurricular activities and corporate culture of the HEE. HEE 2 for this group of target audience is the most attractive than other establishments of higher education, in terms of the stability of sets of applicants for higher education and employment opportunities for graduates. HEE 3 looks a bit better in the eyes of parents of applicants in terms of educational and extracurricular activities, as well as the development of corporate culture, but in all other parameters, except the quality of the educational process, lags behind other establishments (Fig. 6). 


\section{Score in points}

$\begin{array}{lllll}1 & 2 & 3 & 4 & 5\end{array}$

Low quality of the educational process

High tuition fees

Unattractive visual characteristics

Low enrollment of HEE applicants and low employment opportunities after graduation

Uninteresting educational and extracurricular work Underdeveloped corporate culture and

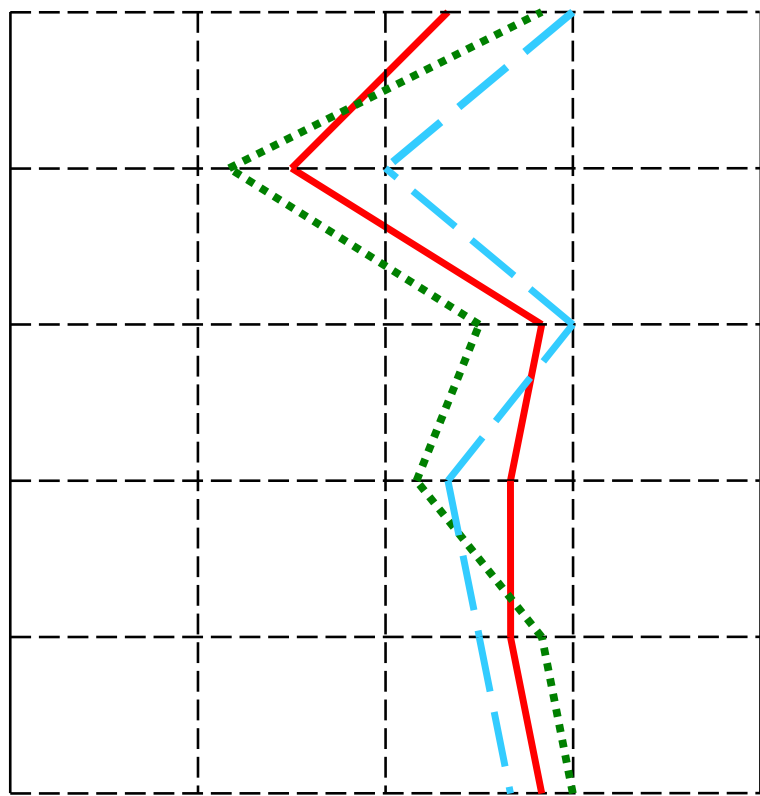
traditions of $\mathrm{HEE}$
High quality of the educational process

Low tuition fees

Attractive visual characteristics

High enrollment of HEE applicants and high employment opportunities after graduation

Interesting educational and extracurricular work

Developed corporate culture and traditions of HEE

HEE 3

\section{HEE 1}

HEE 2

hments by parents of applicants

The authors also considered first-year students' image score. Statistical series of score assessment of the image are presented in table 4.

Table 4. Score assessment of the parameters of HEE image made by first-year students (number of answers, pcs.)

\begin{tabular}{|c|c|c|c|c|c|c|c|c|c|c|c|c|c|c|c|c|}
\hline \multirow{3}{*}{ № } & \multirow{3}{*}{ Image parameter } & \multicolumn{15}{|c|}{ Score (in points) } \\
\hline & & \multicolumn{5}{|c|}{ HEE 1} & \multicolumn{5}{|c|}{ HEE 2} & \multicolumn{5}{|c|}{ HEE 3} \\
\hline & & 1 & 2 & 3 & 4 & 5 & 1 & 2 & 3 & 4 & 5 & 1 & 2 & 3 & 4 & 5 \\
\hline 1. & $\begin{array}{l}\text { The quality of educational } \\
\text { process }\left(X_{1}\right)\end{array}$ & 2 & 4 & 12 & 17 & 26 & 3 & 21 & 24 & 5 & 8 & 11 & 8 & 21 & 12 & 9 \\
\hline 2. & Training costs $\left(\mathrm{X}_{2}\right)$ & 21 & 17 & 13 & 6 & 4 & 19 & 21 & 13 & 5 & 3 & 14 & 8 & 19 & 13 & 7 \\
\hline 3. & $\begin{array}{l}\text { Visual characteristics of a } \\
\operatorname{HEE}\left(\mathrm{X}_{3}\right)\end{array}$ & 2 & 10 & 13 & 18 & 18 & 11 & 13 & 13 & 16 & 8 & 5 & 14 & 25 & 15 & 2 \\
\hline 4. & $\begin{array}{l}\text { Stability of student } \\
\text { enrollment and } \\
\text { employment opportunities } \\
\text { after graduation }\left(\mathrm{X}_{4}\right)\end{array}$ & 14 & 10 & 19 & 12 & 6 & 0 & 2 & 24 & 21 & 14 & 6 & 17 & 21 & 14 & 3 \\
\hline 5. & $\begin{array}{l}\text { Educational and } \\
\text { extracurricular work }\left(\mathrm{X}_{5}\right)\end{array}$ & 6 & 12 & 9 & 21 & 13 & 3 & 5 & 14 & 28 & 11 & 11 & 13 & 19 & 11 & 7 \\
\hline 6. & $\begin{array}{l}\text { Corporate culture and } \\
\text { traditions of HEE }\left(\mathrm{X}_{6}\right)\end{array}$ & 3 & 5 & 11 & 19 & 23 & 1 & 11 & 9 & 24 & 16 & 10 & 11 & 21 & 9 & 10 \\
\hline
\end{tabular}

The average value of the score of first-year students of each studied element of the HEE 1 image is: 

a) $X_{1}=\frac{1 \times 2+2 \times 4+3 \times 12+4 \times 17+5 \times 26}{61}=4,00$;
b) $X_{2}=\frac{1 \times 21+2 \times 17+3 \times 13+4 \times 6+5 \times 4}{61}=2,26$;
c) $X_{3}=\frac{1 \times 2+2 \times 10+3 \times 13+4 \times 18+5 \times 18}{61}=3,66$;
d) $X_{4}=\frac{1 \times 14+2 \times 10+3 \times 19+4 \times 12+5 \times 6}{61}=2,77$;
e) $X_{5}=\frac{1 \times 6+2 \times 12+3 \times 9+4 \times 21+5 \times 13}{61}=3,38$;
f) $X_{6}=\frac{1 \times 3+2 \times 5+3 \times 11+4 \times 19+5 \times 23}{61}=3,89$

Similarly, the average values of the score of first-year students for each studied element of the HEE 2 and HEE 3 image. As a result of calculations, the following values were obtained for HEE 2: $X_{1}=$ 2,$90 ; X_{2}=2,21 ; X_{3}=2,95 ; X_{4}=3,77 ; X_{5}=3,64 ; X_{6}=3,70 ; 3$ BO $3: X_{1}=3,00 ; X_{2}=2,85 ; X_{3}=2,92 ; X_{4}=2,85$; $X_{5}=2,84 ; X_{6}=2,97$.

The total (average) assessment of the image elements of HEE 1, HEE 2, HEE 3 by all respondents (first-year students) is presented in Fig. 7.

\section{Score in points}

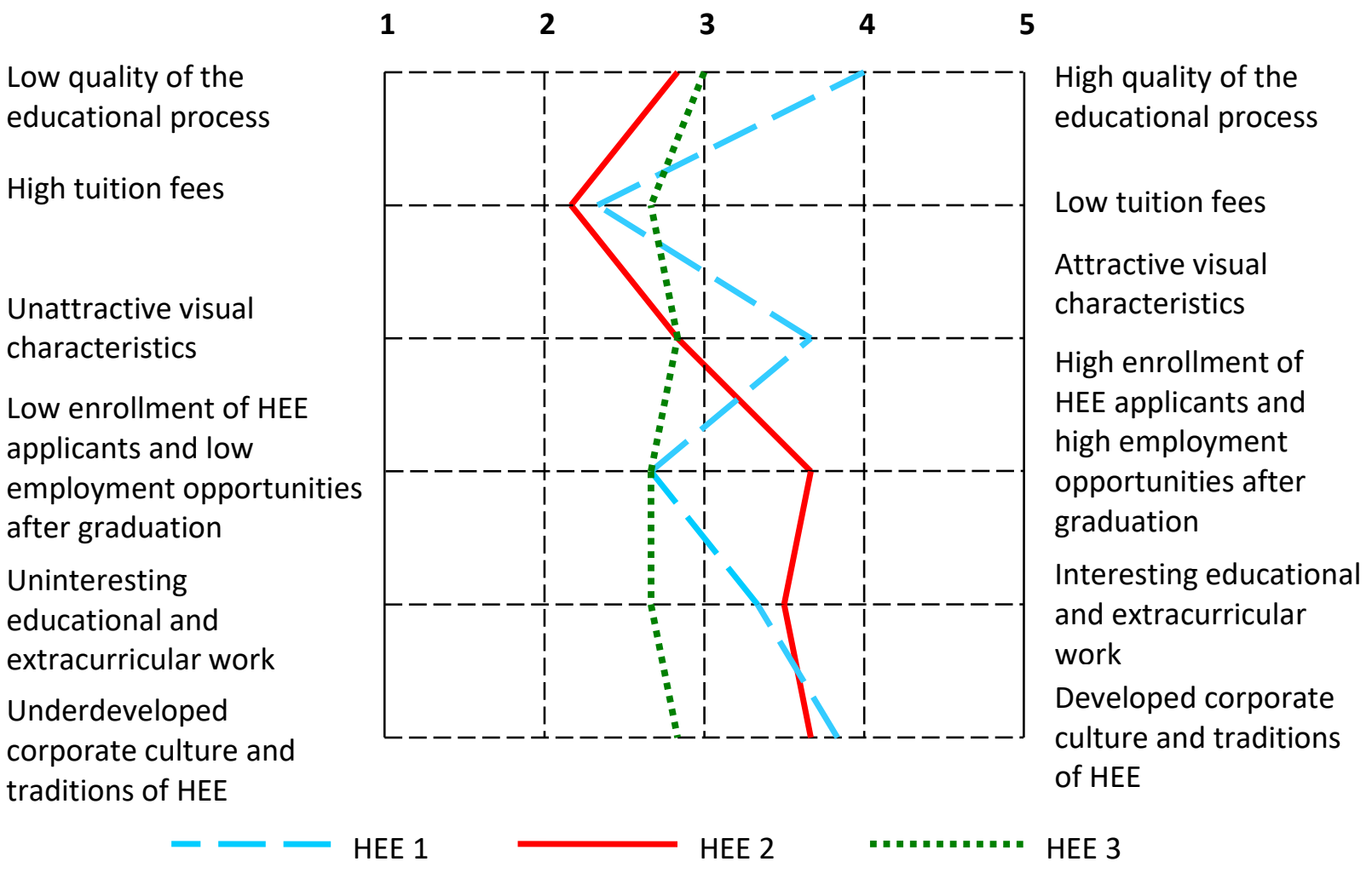

Figure 7. Assessment of the image of higher education establishments by first-year students

Assessing the set of elements of HEE image, we can conclude that in the opinion of first-year students, HEE 1 should improve such image parameters as training costs and stability of employment opportunities after graduation, as well as educational and extracurricular activities. However, the levels of quality of the educational process and visual characteristics of HEE 1 are significantly better than other establishments. HEE 2 has much higher evaluation indicators in terms of the stability of the set of applicants for higher education and the possibility of their employment after graduation and is slightly better in terms of the level of educational and extracurricular activities. HEE 3 is significantly worse in terms of corporate culture and educational and extracurricular activities, and slightly better in terms of training costs.

The generalized results of a point estimation of HEE image are presented in tab. 5. 
Table 5. Summary table of score assessment of the HEE image

\begin{tabular}{|c|c|c|c|c|c|c|c|c|c|}
\hline $\begin{array}{l}E \\
L\end{array}$ & \multicolumn{3}{|c|}{ Applicants } & \multicolumn{3}{|c|}{ Parents of applicants } & \multicolumn{3}{|c|}{ 1st year students } \\
\hline $\begin{array}{l}E \\
N \\
T\end{array}$ & HEE 1 & HEE 2 & HEE 3 & HEE 1 & HEE 2 & HEE 3 & HEE 1 & HEE 2 & HEE 3 \\
\hline$X_{1}$ & 3,69 & 3,67 & 3,87 & 3,95 & 3,32 & 3,78 & 4,00 & 2,90 & 3,00 \\
\hline$x_{2}$ & 2,63 & 3,07 & 3,08 & 2,95 & 2,51 & 2,21 & 2,26 & 2,21 & 2,85 \\
\hline$X_{3}$ & 4,04 & 3,51 & 3,69 & 3,96 & 3,92 & 3,46 & 3,66 & 2,95 & 2,92 \\
\hline $\mathrm{X}_{4}$ & 3,62 & 3,28 & 4,26 & 3,41 & 3,84 & 3,37 & 2,77 & 3,77 & 2,85 \\
\hline$X_{5}$ & 4,17 & 4,02 & 4,03 & 3,47 & 3,71 & 3,84 & 3,38 & 3,64 & 2,84 \\
\hline$X_{6}$ & 3,74 & 3,59 & 3,86 & 3,58 & 3,77 & 3,92 & 3,89 & 3,70 & 2,97 \\
\hline
\end{tabular}

It should be noted that image elements have different levels of importance for respondents. Therefore, the weights of each of the elements were determined. To do this, based on the survey of respondents, the elements of image were assigned the rank of importance.

Therefore, to increase the accuracy of the assessment, the importance of each parameter (element) of the image was taken into account. Respondents were asked to arrange (rank) the studied elements in ascending order of their importance. The minimum rank $a_{i j}=1$ received the least important element. The most important studied element received the maximum rank $a_{i j}=6$. According to the results of ranking, using formula (2), the weighting coefficients qi of each image element were determined (Table 6).

Table 6. Coefficients of weight of image elements for different groups of the target audience

\begin{tabular}{|l|c|c|c|c|c|c|}
\hline \multirow{2}{*}{ Parameter (image element) } & \multicolumn{2}{|c|}{ Applicants } & \multicolumn{2}{c|}{ Parents of applicants } & \multicolumn{2}{c|}{ First-year students } \\
\cline { 2 - 7 } & $\begin{array}{c}\text { The amount of } \\
\text { ranks set by all } \\
\text { respondents }\end{array}$ & $\mathbf{q}_{i}$ & $\begin{array}{c}\text { The amount of } \\
\text { ranks set by all } \\
\text { respondents }\end{array}$ & $\mathbf{q}_{i}$ & $\begin{array}{c}\text { The amount of } \\
\text { ranks set by all } \\
\text { respondents }\end{array}$ & $\mathbf{q}_{i}$ \\
\hline $\begin{array}{l}\text { Educational process } \\
\text { quality }\end{array}$ & 454 & $\mathbf{0 , 2 3}$ & 480 & $\mathbf{0 , 2 4}$ & 317 & $\mathbf{0 , 2 5}$ \\
\hline Price level & 446 & $\mathbf{0 , 2 2}$ & 502 & $\mathbf{0 , 2 5}$ & 267 & $\mathbf{0 , 2 0}$ \\
\hline $\begin{array}{l}\text { Visual characteristics of } \\
\text { HEE }\end{array}$ & 327 & $\mathbf{0 , 1 7}$ & 247 & $\mathbf{0 , 1 3}$ & 183 & $\mathbf{0 , 1 4}$ \\
\hline $\begin{array}{l}\text { Stability of student intake } \\
\text { and employment graduates }\end{array}$ & 428 & $\mathbf{0 , 2 1}$ & 413 & $\mathbf{0 , 2 1}$ & 305 & $\mathbf{0 , 2 4}$ \\
\hline $\begin{array}{l}\text { Educational and } \\
\text { extracurricular work }\end{array}$ & 172 & $\mathbf{0 , 0 9}$ & 188 & $\mathbf{0 , 0 9}$ & 99 & $\mathbf{0 , 0 8}$ \\
\hline $\begin{array}{l}\text { Corporate culture and } \\
\text { traditions of HEE }\end{array}$ & 168 & $\mathbf{0 , 0 8}$ & 165 & $\mathbf{0 , 0 8}$ & 110 & $\mathbf{0 , 0 9}$ \\
\hline Sum & $\mathbf{1 9 9 5}$ & $\mathbf{1}$ & $\mathbf{1 9 9 5}$ & $\mathbf{1}$ & $\mathbf{1 2 8 1}$ & $\mathbf{1}$ \\
\hline
\end{tabular}

Using formula (3), the general image scores were calculated taking into account the weighting factors.

Thus, the assessment of HEEs image in the eyes of applicants:

a) HEE 1: I I HEE $1=3,69 \times 0,23+2,63 \times 0,22+4,04 \times 0,17+3,62 \times 0,21+4,17 \times 0,09+3,74 \times 0,08=$ 
$=3,55$;

b) HEE 2: I HEE $2_{2}=3,67 \times 0,23+3,07 \times 0,22+3,51 \times 0,17+3,28 \times 0,21+4,02 \times 0,09+3,59 \times 0,08=$ $=3,45$;

c) HEE 3: $I_{\text {HeE } 3}=3,87 \times 0,23+3,08 \times 0,22+3,69 \times 0,17+4,26 \times 0,21+4,03 \times 0,09+3,86 \times 0,08=$ $=3,76$.

Assessment of the image of HEEs image in the eyes of parents of applicants:

a) HEE 1: I HEE $1=3,95 \times 0,24+2,95 \times 0,25+3,96 \times 0,13+3,41 \times 0,21+3,47 \times 0,09+3,58 \times 0,08=$ $=3,52$;

b) HEE 2: I HEE $2_{2}=3,32 \times 0,24+2,51 \times 0,25+3,92 \times 0,13+3,84 \times 0,21+3,71 \times 0,09+3,77 \times 0,08=$ $=3,38$;

c) HEE 3: $I_{\text {HEE } 3}=3,78 \times 0,24+2,21 \times 0,25+3,46 \times 0,13+3,37 \times 0,21+3,84 \times 0,09+3,92 \times 0,08=$ $=3,28$.

Assessment of the image of HEEs image in the eyes of First-year students:

a) HEE 1: I HEE $1=4,00 \times 0,25+2,26 \times 0,20+3,66 \times 0,14+2,77 \times 0,24+3,38 \times 0,08+3,89 \times 0,09=$ $=3,25$;

b) HEE 2: $I_{\text {HEE } 2}=2,90 \times 0,25+2,21 \times 0,20+2,95 \times 0,14+3,77 \times 0,24+3,64 \times 0,08+3,70 \times 0,09=$ $=3,11$;

c) HEE 3: $I_{\text {HEE } 3}=3,00 \times 0,25+2,85 \times 0,20+2,92 \times 0,14+2,85 \times 0,24+2,84 \times 0,08+2,97 \times 0,09=$ $=2,91$.

Thus, the overall assessment of the image was calculated not only in accordance with the assessments of the components of HEEs image, but also taking into account their importance for respondents (experts). Thus, for applicants HEE 3 has a higher level of image, for their parents and 1st year students - HEE 1, the worst level for target audience groups, respectively, HEE 2 and HEE 3.

Aggregated assessment of HEEs image, taking into account the views of all target groups (applicants, their parents and students) is:

a) HEE $1: I_{3 \text { HEE } 1}=(3,55+3,52+3,25) / 3=3,44$;

b) HEE 2: $I_{3 \text { HEE } 2}=(3,45+3,38+3,11) / 3=3,31$;

c) HEE $3: I_{3 \text { HEE } 3}=(3,76+3,28+2,91) / 3=3,32$.

Thus, the image of HEE 1 has the best rating, the image of HEE 2 and HEE 3 - almost at the same level.

\section{Conclusions}

Taking into account that the image is a guarantee of public confidence in the HEE activities, in order to regulate the relations that arise in its formation, it is necessary to legislate key indicators and mechanism for their formation and evaluation in licensing activities for educational services, which will increase legal regulation and avoidance conflicts in the cooperation of HEE with public authorities, stakeholders, business, etc.

The authors improved the methodological approach to quantitative assessment of the image of a higher education establishment. This approach is based on the structure of the image of higher education establishment for selected target audiences, provides comprehensive assessment and takes into account the significance (weight) of selected parameters evaluation. The image of higher education establishments was evaluated for three groups of the target audience: applicants, their parents and first-year students of higher education establishments of Ukraine, which showed that the image is better according to the following selected parameters: 1 ) the best educational process quality: in applicants' opinion is HEE 3, for their parents and first-year students - HEE $1 ; 2$ ) the best level of training costs: for applicants and first-year students - HEE 3, for their parents - HEE 1 ; 3) the 
best visual characteristics of HEE: for applicants, their parents and first-year students - HEE 1 ; 4) the best stability of student intake and employment graduates: for applicants - HEE 3, for their parents and first-year students - HEE 2;5) the best educational and extracurricular work as for applicants HEE 1, for their parents - HEE 3, for first-year students - HEE 2; 6) the best corporate culture and traditions of HEE: for applicants and their parents - HEE 3, as for first-year students - HEE 1.

Thus, taking into account the results of the survey to determine the opinions of all groups of the target audience, the image of HEE 1 is the best.

The author's approach is important for the general approach to the management of the HEE image, analysis and selection of forms, methods, mechanisms and tools of such management, search and justification of the place and role of image management in the management of the entire higher education establishment.

\section{Acknowledgements}

The publication contains the results of studies conducted on the initiative research work "Marketing and logistics mechanisms for managing the innovative development of economic entities" (0120U104616).

\section{References}

1. Akoff, R. (2000). Planning the future of the corporation. Moscow: Infra-M, $325 \mathrm{p}$.

2. Aloshina, I. (1997). Public relations for managers and marketers. Moscow: INFRA-M, $266 \mathrm{p.}$

3. Azoury, N.; Daou, L.; Khoury, C. (2014). University Image And Its Relationship To Student Satisfaction- Case of The Middle Eastern Private Business Schools. International Strategic

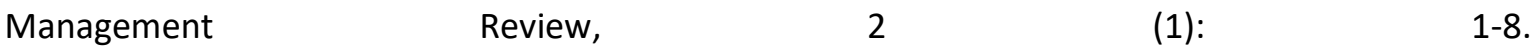
https://www.sciencedirect.com/science/article/pii/S2306774814000076.

4. Alghamdi.A, 2020 "Analyzing the Barriers and Possibilities with p-values towards Starting a New Postgraduate Computer and Engineering Programs at Najran University: A Cross-Sectional Study," International Journal of Advanced Computer Science and Applications (IJACSA), vol. 11, no. 12, 59/31, doi: 10.14569/IJACSA.2020.0111215.

5. Babenko, V.O.; Yatsenko, R.M.; Migunov, P.D.; Salem, A.-B.M. (2020). MarkHub Cloud Online Editor as a modern web-based book creation tool. CEUR Workshop Proceedings, 2643: 174-184. URL: http://ceur-ws.org/Vol-2643/paper09.pdf.

6. Babych, K.; Lakhno, I. (1997). Evaluation of the image of an industrial enterprise. Business-Inform, 8: 47-58.

7. Bila, O.; Gontareva, I.; Babenko, V.; Kovalenko, O.; Gliebova, N. (2019). Organizational and Methodological Guidelines for Training Education Managers to Implement the Strategy of Corporate Social Responsibility. International journal of circuits, systems and signal processing, 14: 679-685. doi: 10.46300/9106.2020.14.87.

8. Bilovodska, O.; Golysheva, I.; Gryshchenko, O.; Strunz, H. (2017). Theoretical and practical fundamentals of scientific and educational projects: a case of Ukraine. Journal of International Studies, 2: 119-128. doi: 10.14254/2071-8330.2017/10-2/8.

9. Bilovodska, O.; Kholostenko, A.; Mandrychenko, Zh.; Volokitenko, O. (2021). Innovation management of enterprises: legal provision and analytical tools for evaluating business strategies. Journal of Optimization in Industrial Engineering, 14 (1): 89-96. URL : http://www.qjie.ir/article_677820_05763483c76a89d1fb9b4b6f865089ae.pdf.

10.Bilovodska, O.; Melnyk, Yu.; Alenin, Yu.; Arkusha, L. (2020). Implementation of Marketing and Legal Tools in the Process of Commercialization for Innovative Products in Strategic Management and Entrepreneurship. International Journal for Quality Research, 14 (4): 1261-1278. URL: 
http://www.ijqr.net/paper.php?id=880.

11.Bilovodska, O.; Starostina, A.; Vovk, V.; Moroz, O.; Moroz, M. (2020). Environmental packaging in trade logistics and innovative entrepreneurship based on Internet marketing online research and communications. Estudios de Economia Aplicada: 38-3 (1). doi: 10.25115/eea.v38i3\%20(1).3993.

12.Chmutova, I.; Vovk, V.; Bezrodna O. (2017). Analytical tools to implement integrated bank financial management technologies. Economic Annals-XXI, 163(1-2(1)): 95-99.

13.Del-Castillo-Feito, C.; Blanco-González, A.; González-Vázquez, E. (2019).The relationship between image and reputation in the Spanish public university. European Research on Management and Business Economics, 25 (2): 87-92. https://www.econstor.eu/bitstream/10419/205788/1/s2444883418301943.pdf

14.Dzhi, B. (2000). Company image. Planning, formation, promotion. SPb: Izdatelstvo Piter, 224 p.

15.Kholiavko, N.; Chekhovych, T.; Mirshuk, O.; Vovk, V. (2020). Integrated model of the competitive higher education: Legal, economic and psycho-pedagogical aspects. International Journal of Industrial Engineering and Production Research, 31(4): 535-545. doi: 10.22068/ijiepr.31.3.535.

16.Kostynets, V.; Kostynets, Y. (2013). Brand assets management model for free economic zone Kurortopolis Truskavets. Actual Problems of Economics, 144(6): 80-85.

17.Kouda, V.; Pasko, M. (2018). Theoretical Aspects of Creating the Image of a Higher Education Establishment. The Problems of Economy, 3 (37): 113-121. https://www.problecon.com/export_pdf/problems-of-economy-2018-3_0-pages-113_121.pdf

18. Miroshnichenko, D.; Zlenko, A.; Isaykina, O. (2017). Image as a Part of Corporative Culture of Modern Higher Educational Establishment. University Economic Bulletin, 34(1): 7-15. https://economic-bulletin.com/index.php/journal/article/view/134.

19.Muhammad, A., Shaikh, A., Naveed, Q. N., \& Qureshi, M. R. N. (2020). Factors affecting academic integrity in E-learning of Saudi Arabian Universities. An investigation using Delphi and AHP. IEEE Access, 8, 16259-16268.

20.Mykytiuk, N. (2001). Marketing Research: Classification and Characterization of Types and Methods. Bulletin of the National University "Lviv Polytechnic". Series: Logistics, 416: 66-74.

21.Olshanska, O.; Gumennykova, T.; Bila, O.;...Perova, S.; Ivannikova, M. (2019). Building a competency model student training. International Journal of Engineering and Advanced Technology, 8(6): 2689-2695.

22.Patlán Pérez, J.; Martínez Torres, E. (2017). Evaluation of the organizational image of a university in a higher education establishment. Contaduría y Administración, 62 (1): 123-140. https://www.elsevier.es/es-revista-contaduria-administracion-87-articulo-evaluationorganizational-image-university-in-S0186104216300699.

23.Perevozova, I.; Babenko, V.; Krykhovetska, Z.; Popadynets, I. (2020). Holistic approach based assessment of social efficiency of research conducted by higher educational establishments. E3S Web of Conferences, 166, id. 13022. doi: 10.1051/e3sconf/202016613022.

24.Schein, E.; Schein, P. (2016). Organizational Culture and Leadership. 5th Edition. John Wiley \& Sons, $416 \mathrm{p}$.

25.The Constitution of Ukraine. Constitution, Law of June 28, 1996. Official web portal of the Verkhovna Rada of Ukraine. URL: http://zakon3.rada.gov.ua/laws/show/254\% D0\% BA / 96-\% D0\% B2\% D1\% 80.

26. The Law of Ukraine "On Higher Education" of 01.07.2014 № 1556-VII. 2014. URL: https://zakon.rada.gov.ua/laws/show/1556-18.

27.The National Doctrine of Education Development: Decree of Ukrainian President of April 17, 2002 
№ 347/2002. Official web portal of the Verkhovna Rada of Ukraine. URL: http://zakon2.rada.gov.ua/laws/show/347/2002.

28.The Recommendations On The Application of The Criteria Evaluation Of Educational Quality Programs. National Agency for Higher Education Quality Assurance of November 17, 2020. URL: https://naqa.gov.ua/wp-content/uploads/2020/12/Рекомендації-щодо-застосування-критеріївоцінювання-якості-ОП.pdf.

29.The Resolution of The Cabinet of Ministers of December 30, 2015 № 1187 "On approval of the License conditions for educational activities". 2015. URL: https://zakon.rada.gov.ua/laws/show/ 1187-2015-\% D0\% BF.

30.The State National Program "Education" ("Ukraine of The Xxi Century"): Resolution of the Cabinet of Ministers of Ukraine, Program, Measures of November 3. 1993 № 896. Official web portal of the Verkhovna Rada of Ukraine. URL: http://zakon5.rada.gov.ua/laws/ show / 896-93-\% D0\% BF.

31.Yevtushenko, G.; Pilipchuk, V.; Smirnova, N. (2016). Features of the Positioning Process of University in the Educational Market. Scientific Bulletin of Uzhhorod National University. Series: International Economic Relations and the World Economy, 7(3): 102-107. http://www.visnykeconom.uzhnu.uz.ua/archive/7_3_2016ua/28.pdf. 